\title{
Effects of 1-MCP on External Postharvest Qualities and Shelf Life of 'Maha Chanok' Mango Fruit
}

\author{
B. Chutichudet ${ }^{1}$, Prasit Chutichudet ${ }^{1} \&$ Usana Trainoak $^{1}$ \\ ${ }^{1}$ Department of Agricultural Technology, Faculty of Technology, Mahasarakham University, Mahasarakham, \\ Thailand
}

Correspondence: B. Chutichudet, Department of Agricultural Technology, Faculty of Technology, Mahasarakham University, Mahasarakham 44150, Thailand. Tel: 66-858-585-450. E-mail: benjawan.c@msu.ac.th

Received: September 15, 2015 Accepted: October 27, 2015 Online Published: December 15, 2015

doi:10.5539/jas.v8n1p68

URL: http://dx.doi.org/10.5539/jas.v8n1p68

\begin{abstract}
'Maha Chanok' mango is an economic fruit crop widely cultivated commercially throughout Thailand. By nature, mango fruit has a rather limited storage life after harvest. 1-methylcyclopropene (1-MCP) has been accepted as a commercial substance to improve several fruit qualities. The objective of this research was to study the effects of 1-MCP on the external postharvest qualities and storage life on the 'Maha Chanok' mango fruit. The experiment was laid out in a Completely Randomized Design with three replicates, ten fruits per replicate. Mango fruit was fumigated with 1-MCP at three concentrations $\left(1000,1250\right.$, or $\left.1500 \mathrm{nl} \mathrm{l}^{-1}\right)$ and three fumigation periods $(12,18$, or $24 \mathrm{~h}$ ), compared with the control fruit. After treating, all treatments were stored under ambient temperature $\left(27{ }^{\circ} \mathrm{C}, 80 \%\right.$ R.H.). The following determinations were made every two days for assessment of fruit weight loss, firmness, chlorophyll content, decay incidence, and storage life. The results showed that fruit treated with 1500 $\mathrm{nl} \mathrm{l}^{-1}$ 1-MCP for $24 \mathrm{~h}$ had the maximal fruit firmness. For chlorophyll content, the results showed that fruit-treated with $1500 \mathrm{nl} \mathrm{l}^{-1}$ 1-MCP for $12 \mathrm{~h}$ could effectively retain the highest chlorophyll contents. Furthermore, both the lowest fruit decay and the longest storage life of 12 days were achieved from the fruit treated with $1000 \mathrm{nl} \mathrm{l}^{-1} 1-\mathrm{MCP}$ for $12 \mathrm{~h}$.
\end{abstract}

Keywords: disease appearance, firmness, 'Maha Chanok' mango, 1-MCP, storage life

\section{Introduction}

Mango (Mangifera indica L.) belongs to the Anacardiaceae family which is widely grown in tropical and subtropical regions (Laohaprasit, Kukreja, \& Arunrat, 2012). It is also one of the most popular fruits consumed both in fresh and processed form (Vidhu, Chourasia, \& Nath, 2005). In Thailand, mango is one of the most preferred and broadly distributed fruits. It can be found throughout the numerous regions in the country, and as such, it is considered an important economic fruit (Wongkhot, Rattanapanone, \& Chanasut, 2012). In Thailand, there are many popular cultivars of mangoes grown for export, including, Chok-Anan, Nam Dok Mai, Nang Klangwan, and Maha Chanok (Wongkhot, Rattanapanone, \& Chanasut, 2012). The 'Maha Chanok' mango is perhaps the most popular cultivar for consumption at the ripe stage (Thai Mango-Ma-Muang, 2008). Cavan (2012) reported that the Maha Chanok is a hybrid cultivar between Sunset and Nang Klangwan-Thailand's local mangos. When the 'Maha Chanok' mango fruit ripens, its skin turns yellowish-orange with a pink blush color (Cavan, 2012). The reasons why many people like to eat them vary, but primarily it is because their flesh has a buttery taste, is juicy, sweet, and fragrant. In addition, 'Maha Chanok' has a high flesh yield (70.5\%) and is a little fibrous (Vásquez-Caicedo et al., 2002; Good Fruit Guide, 2011). For nutritional value the 'Maha Chanok' mango is rich in vitamin $\mathrm{C}, \mathrm{B}_{1}, \mathrm{~B}_{2}$, beta carotene, carbohydrates, protein, calcium, phosphorus, and antioxidant potential (Vásquez-Caicedo et al., 2002). Thailand is the world's fourth ranked mango producing country (1845.6 thousand tones production), with a $27 \%$ share of the world market and an emphasis in Japan and Europe (Wongkaew \& Likittrakoolrung, 2009). Unfortunately, mango fruit is a climacteric fruit; it has poor storage life after harvest due to fast ripening caused by the ripening trigger ethylene, which greatly affects a loss in its commercial value (Wongkhot, Rattanapanone, \& Chanasut, 2012). The rapid quality loss and short storage life of the mango fruit makes it highly perishable with short shelf-life periods (Pantastico, Chattopadhyay, \& Subramanyam, 1975). 
1-Methylcyclopropene (1-MCP) is being considered as an emerging tool with satisfactory results in terms of extending shelf life and quality improvement in several fruits (Blankenship \& Dole, 2003). It is considered as a non-toxic agent for humans and environment (Yuan, Sun, Yuan, \& Wang, 2010). 1-MCP has been reported to have inhibitory effects on ethylene action (Serek, Sisler, \& Reid, 1995) for controlling of ripening and senescence of harvested fruits. Thus, 1-MCP is being commercially used in extending storage life in several perishable fruits (Watkins, 2006). Some examples of the beneficial effects of 1-MCP in postharvest fruits have been recently reviewed, including, delay of weight loss (Blankenship and Dole, 2003), maintenance of fruit firmness, a decreased susceptibility to postharvest decay (Hernández, Barrera, Martínez, \& Fernández-Trujillo, 2009), and prolonging storage life (Rupinder \& Dwivedi, 2008). The aim of this study was to study the effects of 1 -MCP treatments at three concentrations $\left(1000,1250\right.$, and $\left.1500 \mathrm{nl} \mathrm{l}^{-1}\right)$ with three different fumigation period (12, 18 , or $24 \mathrm{~h}$ ) in an attempt to slow down the external postharvest changes and extending the storage life of 'Maha Chanok' mango fruit stored at ambient temperature.

\section{Method}

'Maha Chanok' mango was harvested at commercial maturity based on 98 days after full bloom from a commercial orchard in Kalasin province, in the Northeast region of Thailand. Following the harvest the mangoes were transported to the laboratory within $2 \mathrm{~h}$. Mangoes with uniform fruits size free from visual symptoms of any disease or blemishes were selected for the experiment. The experimental design was Completely Randomized Design, composed of ten treatments, including Control (no treat 1-MCP), treated with 1-MCP at $1000 \mathrm{nl} \mathrm{l}^{-1}$ for 12,18 or $24 \mathrm{~h}$, treated with 1-MCP at $1250 \mathrm{nl} \mathrm{l}^{-1}$ for 12,18 or $24 \mathrm{~h}$, treated with $1-\mathrm{MCP}$ at $1500 \mathrm{nl} \mathrm{l}^{-1}$ for 12, 18 or $24 \mathrm{~h}$. Each treatment was carried out in three replicates with 10 mango fruits per replication. The experiment was carried out from September to February 2013 at the Division of Agricultural Technology, Mahasarakham University, in the northeast of Thailand. After selecting, the fruit were placed in a $20 \mathrm{~L}$ sealed container and exposed to 1-MCP with three concentrations $\left(1000,1250\right.$, or $1500 \mathrm{nl} \mathrm{l}^{-1}$ for three different duration period (12, 18 , or $24 \mathrm{~h}$ ) at $25^{\circ} \mathrm{C}$. The source of 1-MCP was from Mr. Xisheng Sun, by Agrofresh, Inc., China as a powder (active ingredient $0.43 \%$ ), that after addition of warm water $\left(40{ }^{\circ} \mathrm{C}\right)$, released the active ingredient to generate 1-MCP gas. The control fruits were also placed in similar closed containers without the addition of 1-MCP treatment. Following 1-MCP treatment, mango from all treatments were placed into corrugated boxes and stored at an ambient temperature of $27{ }^{\circ} \mathrm{C}$ and $80 \%$ R.H. The external postharvest changes, including, fruit weight loss, firmness, chlorophyll content, fruit decay, and storage life, were evaluated in two day intervals. Fruit weight was determined by weighing individual fruit at two day intervals throughout storage and expressed as the percentage of fruit weight loss from the initial weight. Fruit firmness was determined on two opposite sides of each fruit using a hand-held fruit firmness tester (Effegi, Italy) equipped with a cylindrical plunger $0.5 \mathrm{~cm}$ in diameter and expressed as $\mathrm{kg} \mathrm{cm}^{-2}$. Chlorophyll content was determined using a procedure as described by Whitham, Blaydes, and Devlin (1986) and expressed as $\mathrm{mg} \mathrm{m}^{-2}$. Disease incidence on mango fruit was assessed by observing the extent of total decayed area on each fruit surface. The visual estimation was then noted as a percentage of fruit decay (Terry \& Joyce, 2000). The end of storage life (days) was considered to terminate when $50 \%$ of mango fruit senescence. The comparisons among means were done by the Least Significant Difference (LSD) at P $\leq$ 0.05. The collected data were statistically analyzed using the SPSS Computer Program, Version 6 (SPSS, 1999).

\section{Results}

After fumigating with 1-MCP at three different concentrations of 1000, 1250 or $1500 \mathrm{nl} \mathrm{l}^{-1}$, for three exposure times of 12,18 , or $24 \mathrm{~h}$ the fruit were compared with the control and then stored at ambient temperature $\left(27^{\circ} \mathrm{C}\right.$, $80 \%$ R.H.). The results are presented as follows:

\subsection{Weight Loss}

The data from Table 1 reveal that weight loss of mango fruit in all treatments increased steadily with storage duration. All mango fruits exposed to 1-MCP at three concentrations and three duration periods showed the similar fruit weight loss throughout storage, except on the sixth day after storage (DAS). On the 6 DAS, fruits treated with $1250 \mathrm{nl} \mathrm{l}^{-1} 1$-MCP for $12 \mathrm{~h}$ showed the maximal weight loss of $11.24 \%$, while fruit-treated with $1000 \mathrm{nl} \mathrm{l}^{-1} 1$-MCP for $24 \mathrm{~h}, 1250 \mathrm{nl} \mathrm{l}^{-1} 1$-MCP for $18 \mathrm{~h}, 1250 \mathrm{nl} \mathrm{l}^{-1} 1$-MCP for $24 \mathrm{~h}$ and $1500 \mathrm{nl}^{-1} 1$-MCP for 24 $\mathrm{h}$ showed a significantly minimum weight loss of $8.25,8.11,8.04$ and $8.30 \%$, respectively (Table 1 ). 
Table 1. Weight loss of 'Maha Chanok' mango fruit-treated with 1-MCP

\begin{tabular}{|c|c|c|c|c|c|}
\hline \multirow{2}{*}{ Treatments } & \multicolumn{5}{|c|}{ Weight loss (\%) at DAS } \\
\hline & 2 & 4 & 6 & 8 & 10 \\
\hline Control & 3.09 & 5.77 & $8.65 \mathrm{ab}$ & 11.18 & 14.08 \\
\hline 1-MCP $1000 \mathrm{nl} \mathrm{l}^{-1} 12 \mathrm{~h}$ & 3.40 & 6.13 & $9.42 \mathrm{ab}$ & 11.58 & 14.16 \\
\hline 1-MCP $1000 \mathrm{nl} \mathrm{l}^{-1} 18 \mathrm{~h}$ & 3.39 & 6.46 & $9.37 \mathrm{ab}$ & 12.92 & 16.08 \\
\hline 1-MCP $1000 \mathrm{nl} \mathrm{l}^{-1} 24 \mathrm{~h}$ & 2.77 & 5.23 & $8.25 b$ & 11.02 & 13.04 \\
\hline 1-MCP $1250 \mathrm{nl} \mathrm{l}^{-1} 12 \mathrm{~h}$ & 3.51 & 6.94 & $11.24 \mathrm{a}$ & 14.24 & 17.17 \\
\hline 1-MCP $1250 \mathrm{nl} \mathrm{l}^{-1} 18 \mathrm{~h}$ & 3.11 & 5.55 & $8.11 \mathrm{~b}$ & 11.07 & 14.12 \\
\hline 1-MCP $1250 \mathrm{nl} \mathrm{l}^{-1} 24 \mathrm{~h}$ & 2.87 & 5.44 & $8.04 \mathrm{~b}$ & 10.62 & 13.18 \\
\hline 1-MCP $1500 \mathrm{nl} \mathrm{l}^{-1} 12 \mathrm{~h}$ & 3.42 & 6.14 & $10.11 \mathrm{ab}$ & 11.99 & 15.01 \\
\hline 1-MCP $1500 \mathrm{nl} \mathrm{l}^{-1} 18 \mathrm{~h}$ & 3.18 & 5.55 & $8.69 \mathrm{ab}$ & 11.21 & 13.59 \\
\hline 1-MCP $1500 \mathrm{nl} \mathrm{l}^{-1} 24 \mathrm{~h}$ & 3.30 & 5.57 & $8.30 \mathrm{~b}$ & 10.94 & 13.76 \\
\hline F-test & ns & ns & $*$ & ns & ns \\
\hline LSD & 0.5467 & 0.9166 & 1.3736 & 1.9015 & 2.2664 \\
\hline C.V. $(\%)$ & 8.97 & 10.45 & 11.87 & 14.78 & 15.66 \\
\hline
\end{tabular}

Note. Data were expressed as mean \pm standard deviation (S.D.). Letters within columns indicate least significant differences $(\mathrm{LSD})$ at $\mathrm{P}^{*}=0.05, \mathrm{NS}=$ non significant.

\subsection{Fruit Firmness}

Highly significant differences in fruit firmness were found between 1-MCP-treated fruit and controls. Mango fruit firmness began to show significant differences throughout storage. Fruit-treated with $1500 \mathrm{nl} \mathrm{l}^{-1} 1$-MCP for $24 \mathrm{~h}$ tended to show the maximal fruit firmness from 4 DAS to 10 DAS. On the contrary, Control fruits firmness was at its lowest level during storage (Table 2).

Table 2. Fruit firmness of 'Maha Chanok' mango fruit-treated with 1-MCP

\begin{tabular}{|c|c|c|c|c|c|}
\hline \multirow{2}{*}{ Treatments } & \multicolumn{5}{|c|}{ Fruit firmness $\left(\mathrm{kg} \mathrm{cm}^{-2}\right)$ at DAS } \\
\hline & 2 & 4 & 6 & 8 & 10 \\
\hline Control & $5.13 \mathrm{f}$ & $2.68 \mathrm{f}$ & $2.08 \mathrm{e}$ & $1.61 \mathrm{~d}$ & $1.16 \mathrm{~d}$ \\
\hline 1-MCP1000 nl l-1 $12 \mathrm{~h}$ & $5.48 \mathrm{f}$ & $3.19 \mathrm{e}$ & $2.53 \mathrm{~d}$ & $2.45 \mathrm{c}$ & $2.42 b$ \\
\hline 1-MCP1000 nl l-1 $18 \mathrm{~h}$ & $6.15 \mathrm{de}$ & $3.01 \mathrm{e}$ & $3.02 \mathrm{c}$ & $2.97 \mathrm{ab}$ & $2.37 b$ \\
\hline 1-MCP1000 $\mathrm{nl} \mathrm{l}^{-1} 24 \mathrm{~h}$ & $5.71 \mathrm{e}$ & $3.51 \mathrm{c}$ & $3.23 b$ & $3.02 \mathrm{a}$ & $2.84 \mathrm{~b}$ \\
\hline $1-\mathrm{MCP} 1250 \mathrm{nl} \mathrm{l}^{-1} 12 \mathrm{~h}$ & $7.91 \mathrm{c}$ & $3.24 d$ & $3.01 \mathrm{c}$ & $2.80 \mathrm{~b}$ & $2.11 \mathrm{c}$ \\
\hline 1-MCP1250 $\mathrm{nl} \mathrm{l}^{-1} 18 \mathrm{~h}$ & $6.31 d$ & $3.51 \mathrm{c}$ & $3.27 b$ & $2.58 \mathrm{bc}$ & $2.12 \mathrm{c}$ \\
\hline $1-\mathrm{MCP} 1250 \mathrm{nl} \mathrm{l}^{-1} 24 \mathrm{~h}$ & $5.88 \mathrm{de}$ & $3.67 \mathrm{~b}$ & $2.95 \mathrm{~cd}$ & $2.89 \mathrm{ab}$ & $2.53 \mathrm{bc}$ \\
\hline $1-\mathrm{MCP} 1500 \mathrm{nl} \mathrm{l}^{-1} 12 \mathrm{~h}$ & $5.92 \mathrm{de}$ & $3.17 \mathrm{~d}$ & $3.02 \mathrm{c}$ & $2.66 \mathrm{~b}$ & $2.39 b$ \\
\hline $1-\mathrm{MCP} 1500 \mathrm{nl} \mathrm{l}^{-1} 18 \mathrm{~h}$ & $10.57 \mathrm{a}$ & 3.26 & $2.94 \mathrm{~cd}$ & $2.85 \mathrm{ab}$ & $2.84 b$ \\
\hline 1-MCP1500 nl l-1 $24 \mathrm{~h}$ & $9.96 \mathrm{ab}$ & $4.19 \mathrm{a}$ & $4.04 \mathrm{a}$ & $2.85 \mathrm{ab}$ & $3.50 \mathrm{a}$ \\
\hline F-test & * & $*$ & $*$ & $*$ & $*$ \\
\hline LSD & 122.8621 & 12.3487 & 15.2046 & 13.25 & 11.259 \\
\hline C.V. (\%) & 16.23 & 4.39 & 4.02 & 5.97 & 5.63 \\
\hline
\end{tabular}

Note. Data were expressed as mean \pm standard deviation (S.D.). Letters within columns indicate least significant differences (LSD) at $\mathrm{P}^{*}=0.05$.

\subsection{Chlorophyll Content}

Chlorophyll values decreased for all treatments during storage. The peel of the Control fruit revealed the lowest 
chlorophyll content throughout the storage period. Thus, Control fruit showed dramatically decreased chlorophyll content and turned completely yellow within 6 days under ambient storage. Interestingly, fruit-treated with $1500 \mathrm{nl} \mathrm{l}^{-1} 1$-MCP for $12 \mathrm{~h}$ had the maximal chlorophyll contents of $0.298,0.215$, and 0.104 $\mathrm{mg} / \mathrm{g}$ fresh weight measured on 4, 6 and 8 DAS, respectively (Table 3). These results indicated that fruit-treated with $1500 \mathrm{nl} \mathrm{l}^{-1} 1$-MCP for $12 \mathrm{~h}$ still had greener skin than untreated fruit.

Table 3. Chlorophyll contents of 'Maha Chanok' mango fruit-treated with 1-MCP

\begin{tabular}{|c|c|c|c|c|c|}
\hline \multirow{2}{*}{ Treatments } & \multicolumn{5}{|c|}{ Chlorophyll content (mg/g FW) at DAS } \\
\hline & 2 & 4 & 6 & 8 & 10 \\
\hline Control & $0.235 \mathrm{c}$ & $0.148 \mathrm{c}$ & $0.078 \mathrm{c}$ & $0.069 \mathrm{c}$ & $0.062 b$ \\
\hline $1-\mathrm{MCP} 1000 \mathrm{nl} \mathrm{l}^{-1} 12 \mathrm{~h}$ & $0.333 \mathrm{ab}$ & $0.222 \mathrm{ab}$ & $0.154 b$ & $0.119 \mathrm{a}$ & $0.107 \mathrm{a}$ \\
\hline 1-MCP $1000 \mathrm{nl} \mathrm{l}^{-1} 18 \mathrm{~h}$ & $0.350 \mathrm{a}$ & $0.303 \mathrm{a}$ & $0.161 b$ & $0.099 \mathrm{ab}$ & $0.079 b$ \\
\hline 1-MCP $1000 \mathrm{nl} \mathrm{l}^{-1} 24 \mathrm{~h}$ & $0.345 \mathrm{ab}$ & $0.231 \mathrm{ab}$ & $0.146 b$ & $0.081 \mathrm{ab}$ & $0.069 \mathrm{~b}$ \\
\hline $1-\mathrm{MCP} 1250 \mathrm{nl} \mathrm{l}^{-1} 12 \mathrm{~h}$ & $0.357 \mathrm{a}$ & $0.289 \mathrm{ab}$ & $0.094 \mathrm{bc}$ & $0.067 \mathrm{~b}$ & $0.063 b$ \\
\hline $1-\mathrm{MCP} 1250 \mathrm{nl} \mathrm{l}^{-1} 18 \mathrm{~h}$ & $0.349 \mathrm{ab}$ & $0.178 b$ & $0.159 \mathrm{~b}$ & $0.104 a$ & $0.079 \mathrm{~b}$ \\
\hline 1-MCP $1250 \mathrm{nl} \mathrm{l}^{-1} 24 \mathrm{~h}$ & $0.334 \mathrm{ab}$ & $0.186 b$ & $0.143 b$ & $0.079 b$ & $0.069 \mathrm{~b}$ \\
\hline 1-MCP $1500 \mathrm{nl} \mathrm{l}^{-1} 12 \mathrm{~h}$ & $0.354 \mathrm{ab}$ & $0.298 \mathrm{a}$ & $0.215 \mathrm{a}$ & $0.104 \mathrm{a}$ & $0.091 \mathrm{ab}$ \\
\hline $1-\mathrm{MCP} 1500 \mathrm{nl} \mathrm{l}^{-1} 18 \mathrm{~h}$ & $0.329 \mathrm{ab}$ & $0.175 b$ & $0.151 b$ & $0.081 \mathrm{ab}$ & $0.071 b$ \\
\hline 1-MCP $1500 \mathrm{nl} \mathrm{l}^{-1} 24 \mathrm{~h}$ & $0.230 \mathrm{c}$ & $0.175 b$ & $0.152 b$ & $0.089 \mathrm{ab}$ & $0.066 \mathrm{~b}$ \\
\hline F-test & * & $*$ & * & $*$ & $*$ \\
\hline LSD & 0.1126 & 0.1324 & 0.1121 & 0.0426 & 0.0358 \\
\hline C.V. (\%) & 10.47 & 10.78 & 10.15 & 7.84 & 6.92 \\
\hline
\end{tabular}

Note. Data were expressed as mean \pm standard deviation (S.D.). Letters within columns indicate least significant differences (LSD) at $\mathrm{P} *=0.05$.

\subsection{Decay Incidence}

Percentage of decay incidence was obtained by considering the number of fruit that showed signs of decay over the initial number of fruit. The cumulative decay during storage was expressed as a percentage of infected fruit. Anthracnose, caused by Colletotrichum spp. was the main postharvest disease that occurred on stored mango fruit. Degree of disease incidence on fruit skin rapidly increased during storage. The results from Table 4 revealed that a significantly lower rot appearance was found in fruit-treated with $1000 \mathrm{nl} \mathrm{l}^{-1} 1-\mathrm{MCP}$ for $12 \mathrm{~h}$ since 4 DAS. At the end of storage (10 DAS), fruit-treated with $1000 \mathrm{nl} \mathrm{l}^{-1} 1$-MCP for $12 \mathrm{~h}$ showed minimal decay incidence by $43.75 \%$. 
Table 4. Fruit decay of 'Maha Chanok' mango fruit after treating with 1-MCP

\begin{tabular}{llllll}
\hline \multirow{2}{*}{ Treatments } & \multicolumn{5}{c}{ Fruit decay (\%) at DAS } \\
\cline { 2 - 6 } & 2 & 4 & 6 & 8 & 10 \\
\hline Control & $25.00 \mathrm{a}$ & $37.50 \mathrm{a}$ & $56.25 \mathrm{a}$ & $62.50 \mathrm{a}$ & $87.50 \mathrm{a}$ \\
$1-\mathrm{MCP} 1000 \mathrm{nl} \mathrm{l}^{-1} 12 \mathrm{~h}$ & $0.00 \mathrm{c}$ & $0.00 \mathrm{~d}$ & $6.25 \mathrm{e}$ & $25.00 \mathrm{~d}$ & $43.75 \mathrm{~d}$ \\
$1-\mathrm{MCP} 1000 \mathrm{nl} \mathrm{l}^{-1} 18 \mathrm{~h}$ & $0.00 \mathrm{c}$ & $0.00 \mathrm{~d}$ & $18.75 \mathrm{~d}$ & $50.00 \mathrm{bc}$ & $75.00 \mathrm{~b}$ \\
$1-\mathrm{MCP} 1000 \mathrm{nl} \mathrm{l}^{-1} 24 \mathrm{~h}$ & $0.00 \mathrm{c}$ & $0.00 \mathrm{~d}$ & $25.00 \mathrm{~d}$ & $43.75 \mathrm{c}$ & $75.00 \mathrm{~b}$ \\
$1-\mathrm{MCP} 1250 \mathrm{nl} \mathrm{l}^{-1} 12 \mathrm{~h}$ & $0.00 \mathrm{c}$ & $6.25 \mathrm{c}$ & $50.00 \mathrm{ab}$ & $62.50 \mathrm{a}$ & $93.75 \mathrm{a}$ \\
1 -MCP $1250 \mathrm{nl} \mathrm{l}^{-1} 18 \mathrm{~h}$ & $6.25 \mathrm{~b}$ & $12.50 \mathrm{~b}$ & $37.50 \mathrm{c}$ & $43.75 \mathrm{c}$ & $56.25 \mathrm{c}$ \\
$1-\mathrm{MCP} 1250 \mathrm{nl} \mathrm{l}^{-1} 24 \mathrm{~h}$ & $0.00 \mathrm{c}$ & $0.00 \mathrm{~d}$ & $37.50 \mathrm{c}$ & $56.25 \mathrm{ab}$ & $75.00 \mathrm{~b}$ \\
$1-\mathrm{MCP} 1500 \mathrm{nl} \mathrm{l}^{-1} 12 \mathrm{~h}$ & $0.00 \mathrm{c}$ & $0.00 \mathrm{~d}$ & $18.75 \mathrm{~d}$ & $50.00 \mathrm{bc}$ & $50.00 \mathrm{~cd}$ \\
$1-\mathrm{MCP} 1500 \mathrm{nl} \mathrm{l}^{-1} 18 \mathrm{~h}$ & $0.00 \mathrm{c}$ & $6.25 \mathrm{c}$ & $25.00 \mathrm{~d}$ & $43.75 \mathrm{c}$ & $68.75 \mathrm{~b}$ \\
$1-\mathrm{MCP} 1500 \mathrm{nl} \mathrm{l}^{-1} 24 \mathrm{~h}$ & $0.00 \mathrm{c}$ & $0.00 \mathrm{~d}$ & $25.00 \mathrm{~d}$ & $56.25 \mathrm{ab}$ & $87.50 \mathrm{a}$ \\
F-test & $*$ & $*$ & $*$ & $*$ & $*$ \\
LSD & 0.6591 & 1.2505 & 4.2880 & 5.6309 & 5.0480 \\
C.V. (\%) & 19.00 & 24.00 & 16.13 & 13.02 & 8.46 \\
\hline
\end{tabular}

Note. Data were expressed as mean \pm standard deviation (S.D.). Letters within columns indicate least significant differences (LSD) at $\mathrm{P}^{*}=0.05$.

\subsection{Storage Life}

The results from Table 5 show that fruit-treated with $1000 \mathrm{nl} \mathrm{l}^{-1}$ 1-MCP for $12 \mathrm{~h}$ showed a marked effect on the maximal storage life of 14 days, while the Control fruit had the minimal postharvest life of only 8 days.

Table 5. Shelf life of 'Maha Chanok' mango fruit after treating with 1-MCP

\begin{tabular}{ll}
\hline Treatments & Shelf life (days) \\
\hline Control & $8.00 \mathrm{c}$ \\
1 -MCP $1000 \mathrm{nl} \mathrm{l}^{-1} 12 \mathrm{~h}$ & $14.00 \mathrm{a}$ \\
1 -MCP $1000 \mathrm{nl}^{-1} 18 \mathrm{~h}$ & $10.00 \mathrm{bc}$ \\
1 -MCP $1000 \mathrm{nl}^{-1} 24 \mathrm{~h}$ & $10.00 \mathrm{bc}$ \\
1 -MCP $1250 \mathrm{nl} \mathrm{l}^{-1} 12 \mathrm{~h}$ & $8.00 \mathrm{c}$ \\
1 -MCP $1250 \mathrm{nl} \mathrm{l}^{-1} 18 \mathrm{~h}$ & $12.00 \mathrm{ab}$ \\
1 -MCP $1250 \mathrm{nl} \mathrm{l}^{-1} 24 \mathrm{~h}$ & $10.00 \mathrm{bc}$ \\
1 -MCP $1500 \mathrm{nl}^{-1} 12 \mathrm{~h}$ & $12.00 \mathrm{ab}$ \\
1 -MCP $1500 \mathrm{nl}^{-1} 18 \mathrm{~h}$ & $10.00 \mathrm{bc}$ \\
1 -MCP $1500 \mathrm{nl} \mathrm{l}^{-1} 24 \mathrm{~h}$ & $8.00 \mathrm{c}$ \\
F-test & $*$ \\
LSD & 1.5678 \\
C.V. (\%) & 18.56 \\
\hline
\end{tabular}

Note. Data were expressed as mean \pm standard deviation (S.D.). Letters within columns indicate least significant differences $(\mathrm{LSD})$ at $\mathrm{P}^{*}=0.05$.

\section{Discussion}

When considering weight loss, the results revealed that 1-MCP application at three different concentrations with three various exposure periods had no clear effect on the weight loss of 'Maha Chanok' mango fruit. Most of the Control and 1-MCP treated fruits had quite similar weight loss during storage, except on 6 DAS. Thus, the results of this study indicated that weight loss of 'Maha Chanok' mango fruit was ambiguous after treating with 1-MCP. It is possible therefore that 1-MCP treatment were not effective in reducing mango fruit weight loss. There were a few reports that described 1-MCP treatment as being highly effective in reducing weight loss during storage for 
tomato fruits (Guillén et al., 2006), while some researchers described 1-MCP as not affecting fruit weight loss in papaya (Ashariya, Bayogan, Thumdee, \& Paull, 2007).

With respect to pulp firmness, generally, mango ripening is characterized by fruit softening increments (Bassetto, Jacomino, Pinheiro, \& Kluge, 2005). Mango is considered to be a climactic fruit, which typically soften very quickly (Xiaolin, Ye, Jiang, Guox, \& Li, 2012). Menniti, Gregori, and Donati (2004) reported that mango fruit softens rapidly after harvest, because its softening is regulated by endogenous ethylene biosynthesis. Kashif, Khan, Malik, and Shahid (2013) cited that fruit softening is linked with enzymatic changes and textural modifications leading to breakdown of cell wall polymers, such as, cellulose, hemicelluloses and pectin. In mango, various enzymes documented to be involved in softening are polygalacturonase (PG) (Lazan, Ali, Lee, Voon, \& Chaplin, 1986), and $\beta$-1,4-glucanases (Ali, Chin, \& Lazan, 2004). The activity of endo-PG was significantly increased in the pulp tissues of 'Samar Bashist Chaunsa' mango fruit with the advancement of the ripening period. The results from Table 2 indicate that postharvest firmness of 'Maha Chanok' mango can be maintained by treating with $1500 \mathrm{nl} \mathrm{l}^{-1} 1$-MCP for $24 \mathrm{~h}$ during storage. It is possible that 1-MCP treatment was highly effective in reducing ethylene production and delaying fruit softening (Blankenship \& Dole, 2003) by blocking ethylene receptors (Sisler \& Serek, 1997). These results are in agreement with those obtained by Khan and Singh (2007) who showed that postharvest application of 1-MCP significantly lowered the activities of softening enzymes in plum fruit. They reported that plum fruit treated with 1-MCP showed reduced activities of exo-polygalacturonase (exo-PG), and endo-polygalacturonase (endo-PG) enzymes during fruit ripening, and the reduction was more pronounced at the higher concentrations of 1-MCP. Ahmad and Singh (2009) also cited that the application of higher concentrations of 1-MCP to 'Tegan Blue' plum maintained significantly firmer fruit during storage. The reduction in plum fruit softening with 1-MCP treatment may be attributed to suppressed ethylene production, and consequently, the reduction in fruit softening. Similarly, Ahmad and Singh (2009) reported that 1-MCP could retard fruit softening during fruit ripening in climacteric fruit (Watkins, 2006) through inhibiting the activities of cell wall hydrolytic enzymes (Jeong et al., 2002). Accordingly, Kim, Hewett, and Lallu (2001) also found that 1-MCP reduced softening of intact kiwifruit and the effect tended to be concentration dependent. A similar delayed mango fruit softening was also found in mango treated with 25-100 $\mu \mathrm{l}^{-1}$ 1-MCP for $14 \mathrm{~h}$ at $20{ }^{\circ} \mathrm{C}$ (Hofman, Jobin-Décor, Meiburg, Macnish, \& Joyce, 2001). However, after treating with 1-MCP, nonpermanent binding of 1-MCP to ethylene receptors could be turned back and led fruit to ripe normally (Blankenship, 2003). Thus, an effective 1-MCP application to delay fruit softening depended upon the concentration and exposure duration (Singh \& Pal, 2008). This is consistent with the findings of Ekman, Clayton, Biasi, and Mitcham (2004) who cited that the response of fruit firmness to 1-MCP treatment was highly dependent on the 1-MCP concentration application. While Khan and Singh (2007) reported that the reduction of softening enzymes activities was more pronounced as the higher concentrations of 1-MCP were applied (Ahmad $\&$ Singh, 2009). These results are not in agreement with those obtained by Porat et al. (1999) who showed that 1-MCP treatment had no significant effect on firmness retention in citrus fruit and fresh-cut pineapple (Budu \& Joyce, 2003). The contradictory results mentioned above concerning the effects of 1-MCP on fruit firmness related to modified softening enzymes still require a full explanation. No information is available on the effects of 1-MCP on 'Maha Chanok' fruit softening or the activities of fruit softening enzymes during storage. Thus, the mechanism of $1-\mathrm{MCP}$ as it relates to delaying mango fruit softening during storage has not been clearly elucidated and warrants further investigations.

For chlorophyll content, the effect of 1-MCP application on chlorophyll content is illustrated in Table 3. Mango fruit-treated with $1500 \mathrm{nl} \mathrm{l}^{-1} 1$-MCP for $12 \mathrm{~h}$ showed the highest chlorophyll contents which was significantly different from the other treatments of 4 DAS to 8 DAS. These results also showed the positive effects of $1500 \mathrm{nl}$ $\mathrm{I}^{-1} 1$-MCP for $12 \mathrm{~h}$ on delaying the changes of peel color. Peel color of mango fruit-treated with $1500 \mathrm{nl} \mathrm{l} \mathrm{l}^{-1}$ 1-MCP for $12 \mathrm{~h}$ turned less yellow than the others (Pongprasert \& Srilaong, 2014). Several reports have shown the effects of 1-MCP in retarding ripening (Zhanquan, Tian, Zhu, Xu, \& Qin, 2012) by competing with ethylene action, which prevents ethylene from exerting its physiological action (Sisler \& Serek, 1997) and leads to better retention of chlorophyll content in 1-MCP-treated fruit. Cefola, Amodio, Rinaldi, Vanadia, and Colelli (2010) also reported that a cause of retention of the green peel color in fruit-treated with 1-MCP can be attributed to 1-MCP itself; it is an effective inhibitor that reduces the activity of chlorophyllase enzymes involved with chlorophyll degradation. These data support the findings of Vera, Saguy, and Pesis (2005) who found that 1-MCP-treated 'Ettinger' and 'Pinkerton' avocado fruit maintained a greener peel color because of their lower levels of chlorophylls activity and less chlorophyll breakdown. Thus, there is documentation available about the effect of 1-MCP in delaying chlorophyll degradation and causing retention of higher chlorophyll content of fruit peel for longer periods of time in several fruits (Cheng et al., 2012), such as avocado (Jeong, Huber, \& Sargent, 2002), coriander (Jiang, Sheng, Zhou, Zhang, \& Liu, 2002), pear (Liu, Lai, Xu, \& Tian, 2013), cucumber 
(Nilsson, 2005), and peaches (Kluge \& Jacomino, 2002). In addition, Bassetto, Jacomino, Pinheiro, and Kluge (2005) cited that 1-MCP efficiency was directly related to concentration and exposure time. They found that the higher the 1-MCP concentration compared with exposure time to the product, the greater the retention of the green skin color in 'Pedro Sato' guava. These results support the findings of Jiang, Joyce, and Macnish (1999) and Jeong, Huber, and Sargent (2002) that a correlation between concentration and exposure time was also observed in treating banana and avocado with 1-MCP, respectively. In contrast, some researchers found that there was no influence of 1-MCP on postharvest color changes in apricots (Dong, Lurie, \& Zhou, 2002), and sweet cherries (Gong, Fan, \& Mattheis, 2002). While Win, Srilaong, Heyes, Kyu, and Kanlayanarat (2006) found that application with high concentrations of 1- MCP (750 and $\left.1000 \mathrm{nl} \mathrm{l}^{-1}\right)$ significantly damaged the fruit of West Indian lime cv. 'Paan' during ambient storage by promoting chlorophyllase activity, which caused the deleterious results. Similar adverse effects on citrus fruit from high concentrations of 1-MCP have been reported by Porat et al. (2001) who found that exposure of 'Oroblanco' pummelo to 1-MCP at $2000 \mathrm{nl} \mathrm{l}^{-1}$ resulted in faster peel yellowing. However, the results from this research found no large differences in 1-MCP efficacy with different exposure durations of 12, 18 or $24 \mathrm{~h}$. However, it is still unclear how 1-MCP affects chlorophyll content of 'Maha Chanok' mango fruit. Further study of the mechanisms of 1-MCP that may delay chlorophyll degradation should be investigated.

For decay incidence, the susceptibility of mango fruit to postharvest diseases increases during storage as a result of the physiological changes and senescence that favor pathogen development (Prusky \& Keen, 1993). Table 4 showed the percentage in decay incidence of 'Maha Chanok' mango fruit during postharvest after being treated with 1-MCP. The results indicated that 1-MCP treatments had significant effects on postharvest fruit decay. Treating with $1000 \mathrm{nl} \mathrm{l}{ }^{-1} 1$-MCP for $12 \mathrm{~h}$ showed efficacy in slowing the deterioration of 'Maha Chanok' mango fruit during storage at room temperature. These results coincide with previous reports of Pietro, Cocci, Romani, Sacchetti, and Rosa (2009) who found that 1-MCP may be beneficial in controlling microbial growth. Similar results were also reported by several researchers, who reported the positive effects of 1-MCP to enhance the disease resistance in apricots (Dong, Lurie, \& Zhou, 2002), jujube (Zhanquan, Tian, Zhu, Xu, \& Qin, 2012), plums (Valero, Martínez-Romero, Valverde, Guillén, \& Serrano, 2003), loquat (Cai et al., 2006), citrus (Porat et al., 1999). The similar trend in reducing decay appearance after treating with 1-MCP, may be associated with changes in natural antifungal compounds in ripening fruit (Prusky \& Keen, 1993). Zhanquan, Tian, Zhu, Xu, and Qin (2012) indicated that the induced resistance in jujube fruit by 1-MCP is related to an increase of enzymes associated with plant phenolic metabolism which produces highly toxic products against pathogen invasion while Bower, Biasi, and Mitcham (2003) cited that 1-MCP had no effect on the decay of strawberry. In contrast, Jiang, Joyce, and Ferry (2001) pointed out the disadvantage of 1-MCP treatment in controlling postharvest pathogens. They found that 1-MCP could accelerate disease development in strawberries. However, these different responses to 1-MCP may be species specific (Blankenship, 2003) and the concentrations of 1-MCP used (Zhanquan, Tian, $\mathrm{Zhu}, \mathrm{Xu}, \& \mathrm{Qin}, 2012)$. Furthermore, the effects of 1-MCP treatments on fruit decay varied with concentration-dependent (Chong et al., 2006). Similarly, Guillén et al. (2006) pointed out the induction of decay by 1-MCP in strawberry seemed to be dose-dependent, since disease development was accelerated in fruit treated at high 1-MCP concentrations ( 500 and $1000 \mathrm{nl} \mathrm{l}^{-1}$ ), mainly due to inhibition of some beneficial metabolic pathway which contributed to the natural defense system. Hofman, Jobin-Décor, Meiburg, Macnish, and Joyce (2001) also found that 'Hass' avocado fruit treated with a very high concentration $\left(25 \mu \mathrm{l}^{-1}\right)$ of 1-MCP tended to increase the severity of fruit rotting. It is possible that 1-MCP application at high concentration may be associated with adding stress to the received fruit (Adkins, Hofman, Stubbings, \& Macnish, 2005). However, little information is available about the effect of 1-MCP on inducing fruit resistance against postharvest decay and the mechanisms by which 1-MCP shows efficacy in slowing the deterioration of 'Maha Chanok' mango fruit.

With respect to storage life, the best treatment for extending postharvest life proved to be $1000 \mathrm{nl} / 1$ 1-MCP for 12 h. Gómez-Lobato, Hasperué, Civello, Chaves, and Martínez (2012) cited that 1-MCP is an effective inhibitor of ethylene action in a range of perishable fruit, which proved to delay ripening or the senescence process, and led to extend the postharvest life of several fruits (Watkins, 2008). 1-MCP is thought to act by binding irreversibly to ethylene receptors in the fruit, thereby preventing the effects of ethylene in plant tissues (Sisler \& Serek, 1997). Similar effects of 1-MCP on extending postharvest life have been reported in mango (Jiang \& Joyce, 2000), papaya (Jacomino, Kluge, \& Brackmann, 2002), loquat (Chong et al., 2006), 'Qiandaowuhe' persimmon (Zisheng, 2007), and avocado (Jeong, Huber, \& Sargent, 2002). This is in accordance with findings of Juan, Concellón, Chaves, and Vicente (2011) who cited that 1-MCP treatments delayed senescence and maintained the quality of eggplant fruit. These results are consistent with the findings of Shifeng, Yan, and Zheng (2012). Results also suggest that 1-MCP at $1.0 \mu \mathrm{l} \mathrm{l}^{-1}$ applied to green bell pepper was the most effective in delaying senescence, manifested as a delay in chlorophyll degradation and fresh weight loss. In addition, Carrillo, 
Hernández, Barrera, Martínez, and Fernández-Trujillo (2011) reported that the successful application of 1-MCP to fruit is strongly dependent on many factors, such as, cultivar, harvest maturity stage, concentration, exposure time, and temperatures (Sozzi \& Beaudry, 2007). Blankenship (2003) indicated that 1-MCP treatment duration ranged from 12 to $24 \mathrm{~h}$ to achieve a full response. Furthermore, Harima et al. (2003) found that binding of $1-\mathrm{MCP}$ to the ethylene receptor is irreversible; plants could recover their ethylene sensitivity thereafter (Sisler \& Serek, 1997). Thus, the length of the protection period by 1-MCP varies with plant species and tissues. Ella, Zion, Nehemia, and Ammon (2003) revealed that the use of low concentrations of 1-MCP may lead to accelerate the senescence, possibly through the relief of the ethylene auto-inhibitory response. The efficacy of 1-MCP protection is also greatly affected by temperature. The effect of 1-MCP on delaying senescence may be attributed to its ability to inhibit ethylene biosynthesis (Sisler \& Serek, 1997), leading to delayed senescence and maintenance of external quality, such as, delayed fruit softening or a delay in ripening and other changes which may lead to extending the storage life of the fruit (Blankenship \& Dole, 2003). However, the mode of 1-MCP action in delaying senescence and quality deterioration in 'Maha Chanok' mango has not been clearly elucidated. Furthermore, the ability of 1-MCP application in maintaining the internal quality characteristics in stored mango fruit should be studied.

In conclusion, it was found that the shelf life of 'Maha Chanok' mango fruit treated with $1000 \mathrm{nl} \mathrm{l}^{-1} 1$-MCP for $12 \mathrm{~h}$ was extended for up to 14 days. The same treatment resulted in the lowest incidence of decay throughout the storage period.

\section{Acknowledgements}

This research was funded by the Mahasarakham University. The authors wish to express their sincere thanks to the Financial Office for financial assistance. We appreciate the support of Mr. Xisheng Sun, who kindly provided the 1-MCP from AgroFresh Inc. China. We gratefully acknowledge Mr. Paul Dulfer for revising the manuscript and Miss Usana Trainoak for her kind assistance.

\section{References}

Adkins, M. F., Hofman, P. J., Stubbings, B. A., \& Macnish, A. J. (2005). Manipulating avocado fruit ripening with 1-methylcyclopropene. Postharvest Biology and Technology, 35(1), 33-42. http://dx.doi.org/10.1016/j.postharvbio.2004.05.021

Ahmad, S. K., \& Singh, Z. (2009). 1-MCP application suppresses ethylene biosynthesis and retards fruit softening during cold storage of 'Tegan Blue' Japanese plum. Plant Science, 176(4), 539-544. http://dx.doi.org/10.1016/j.plantsci.2009.01.012

Ali, Z. M., Chin, L. H., \& Lazan, H. (2004). A comparative study on wall degrading enzymes, pectin modifications and softening during ripening of selected tropical fruits. Plant Science, 167(2), 317-327. http://dx.doi.org/ 10.1016/j.plantsci.2004.03.030

Ashariya, M., Bayogan, E. R. V., Thumdee, S., \& Paull, R. E. (2007). Utility of 1-methylcyclopropene as a papaya postharvest treatment. Postharvest Biology and Technology, 44(1), 55-62. http://dx.doi.org/10.1016/j.postharvbio. 2006.11.005

Bassetto, E., Jacomino, A. P., Pinheiro, A. L., \& Kluge, R. A. (2005). Delay of ripening of 'Pedro Sato' guava with 1-methylcyclopropene. Postharvest Biology and Technology, 35(3), 303-308. http://dx.doi.org/10.1016/j.post harvbio.2004.08.003

Blankenship, S. M. (2003). 1-Methylcyclopropene: A review. Postharvest Biology and Technology, 28(1), 1-25. http://dx.doi.org/10.1016/S0925-5214(02)002 46-6

Blankenship, S. M., \& Dole, J. M. (2003). 1-Methylcyclopropene: a review. Postharvest Biology and Technology 28(1), 1-25. http://dx.doi.org/10.106/ S0925-5214(02) 00246-6

Bower, J. H., Biasi, W. V., \& Mitcham, E. J. (2003). Effect of ethylene and 1-MCP on the quality and storage life of strawberries. Postharvest Biology and Technology, 28(3), 417-423. http://dx.doi.org/10.1016/S0925-5214(02) 00208-9

Budu, A. S., \& Joyce, D. C. (2003). Effect of 1-methylcyclopropene on the quality of minimally processed pineapple fruit. Australian Journal of Experimental Agriculture, 43(2), 177-184. http://dx.doi.org/10.1071/EA 02029

Cai, C., Chen, K. S., Xu, W. P., Zhang, W. S., Li, X., \& Ferguson, I. B. (2006). Effect of 1-MCP on postharvest quality of loquat fruit. Postharvest Biology and Technology, 40(2), 155-162. http://dx.doi.org/10.1016/j.postharvbio.2005. 12.014 
Carrillo, M. P., Hernández, M. S., Barrera, J., Martínez, O., \& Fernández-Trujillo, J. P. (2011). 1-Methylcyclopropene delays arazá ripening and improves postharvest fruit quality. LWT-Food Science and Technology, 44(1), 250-255. http://dx.doi.org/10.1016/j. lwt.2010.05.029

Cavan, W. (2012). Maha Chanok: Maha Chanok is a hybrid mango between maxican's and Thai's local mangos. Retrieved from http://mangoworldmagazine.blogspot.com/2012/05/maha-chanok-maha-chanok-is-hybridmango.html

Cefola, M., Amodio, M. L., Rinaldi, R., Vanadia, S., \& Colelli, G. (2010). Exposure to 1-methylcyclopropene (1-MCP) delays the effects of ethylene on fresh-cut broccoli raab (Brassica rapa L.). Postharvest Biology and Technology, 58(1), 29-35. http://dx.doi.org/10.1016/j.postharvbio.2010. 05.001

Cheng, Y., Dong, Y., Yan, H., Ge, W., Shen, C., Guan, J., ... Zhang, Y. (2012). Effects of 1-MCP on chlorophyll degradation pathway-associated genes expression and chloroplast ultrastructure during the peel yellowing of Chinese pear fruits in storage. Food Chemistry, 135(2), 415-422. http://dx.doi.org/10.1016/j.foodchem.2012.05.017

Chong, C., Chen, K. S., Xu, W. P., Zhang, W. S., Li, X., \& Ferguson, I. (2006). Effect of 1-MCP on postharvest quality of loquat fruit. Postharvest Biology and Technology, 40(2), 155-162. http://dx.doi.org/10.1016/j.postharvbio.2005.12.014

Dong, L., Lurie, S., \& Zhou, H. (2002). Effect of 1-methylcyclopropene on ripening of "Canino" apricots and "Royal Zee" plums. Postharvest Biology and Technology, 24(2), 135-145. http://dx.doi.org/10.1016/S09 25-5214(01)00130-2

Ekman, J. H., Clayton, M., Biasi, W. V., \& Mitcham, E. J. (2004). Interactions between 1-MCP concentration, treatment interval and storage time for 'Bartlett' pears. Postharvest Biology and Technology, 31(2), 127-136. http://dx.doi.org/10.1016/j.postharvbio. 2003.07.002

Ella, L., Zion, A., Nehemia, A., \& Ammon, L. (2003). Effect of the ethylene action inhibitor 1-methylcyclopropene on parsley leaf senescence and ethylene biosynthesis. Postharvest Biology and Technology, 30(1), 67-74. http://dx. doi.org/10.1016/S0925-5214(03)00080-2

Gómez-Lobato, M. E., Hasperué, J. H., Civello, P. M., Chaves, A. R., \& Martínez, G. A. (2012). Effect of 1-MCP on the expression of chlorophyll degrading genes during senescence of broccoli (Brassica oleracea L.). Scientia Horticulturae, 144(6), 208-211. http://dx.doi.org/10.1016/j.scienta.2012. 07.017

Gong, Y., Fan, X., \& Mattheis, J. P. (2002). Responses of 'Bing' and 'Rainier' sweet cherries to ethylene and 1-methylcyclopropene. Journal of the American Society for Horticultural Science, 127(5), 831-835. http://journal.ashspublications.org/content/127/5/831.short

Good Fruit Guide. (2011). Maha Chanok. Retrieved from http://goodfruitguide.co.uk/fruits/mangoes/maha-chanok

Harima, S., Nakano, R., Yamauchi, S., Kitano, Y., Yamamoto, Y., Inaba, A., \& Kubo, Y. (2003). Extending shelf-life of astringent persimmon (Diospyros kaki Thunb.) fruit by 1-MCP. Postharvest Biology and Technology, 29(3), 319-324. http://dx.doi.org/10.1016/S0925-5214(03)00058-9

Hernández, M. S., Barrera, J., Martínez, O., \& Fernández-Trujillo, J. P. (2009). Postharvest quality of arazá fruit during low temperature storage. LWT-Food Science and Technology, 42(4), 879-884. http://dx.doi.org/10.1016/j. lwt.2008.11.009

Hofman, P. J., Jobin-Décor, M., Meiburg, G. F., Macnish, A. J., \& Joyce, D. C. (2001). Ripening and quality responses of avocado, custard apple, mango and papaya fruit to 1-methylcyclopropene. Australian Journal of Experimental Agriculture, 41(4), 567-572. http://dx.doi.org/10.1071/EA00152

Jacomino, A. P., Kluge, R. A., \& Brackmann, A. (2002). Ripening and senescence of papaya with $\begin{array}{llll}\text { 1-methylcyclopropene. } & \text { Scientia } & \text { Agricola, } & 593-308 .\end{array}$ http://dx.doi.org/10.1590/S0103-90162002000200015

Jiang, Y., \& Joyce, D. C. (2000). Effects of 1-methylcyclopropene alone and in combination with polyethylene bags on the postharvest life of mango fruit. Annals of Applied Biology, 137(3), 321-327. http://dx.doi.org/10.1111/j. 1744-7348.2000.tb00073.x

Jiang, Y. M., Joyce, D. C., \& Macnish, A. J. (1999). Responses of banana fruit to treatment with $\begin{array}{llll}\text { 1-methylcyclopropene. Plant } & \text { Growth } & \text { Regulation, } & \text { 28(2), }\end{array}$ http://dx.doi.org/10.1023/A:1006222631666 
Jiang, Y., Joyce, D., \& Ferry, L. A. (2001). 1-MCP treatment affects strawberry fruit decay. Postharvest Biology and Technology, 23(3), 227-232. http://dx.doi.org/10.1016/ S0925-5214(01) 00123-5

Jiang, W., Sheng, Q., Zhou, X., Zhang, M., \& Liu, X. (2002). Regulation of coriander senescence by 1-methylcyclopropene and ethylene. Postharvest Biology and Technology, 26(3), 339-345. http://dx.doi.org/10.1016/S0925-5214(02)00068-6

Juan, F. M., Concellón, A., Chaves, A. R., \& Vicente, A. R. (2011). 1-Methylcyclopropene (1-MCP) delays senescence, maintains quality and reduces browning of non-climacteric eggplant (Solanum melongena L.) $\begin{array}{lllll}\text { fruit. Postharvest Biology and } & \text { 10-15. }\end{array}$ http://dx.doi.org/10.1016/j.postharvbio.2010.08.007

Kashif, R., Khan, A. S., Malik, A. U., \& Shahid, M. (2013). Ripening period influences fruit softening and antioxidative system of 'Samar Bahisht Chaunsa' mango. Scientia Horticulturae, 160(27), 108-114. http://dx.doi.org/10.1016/j.scienta.2013.05.018

Khan, A., \& Singh, Z. (2007). 1-MCP regulates ethylene biosynthesis and fruit softening during ripening of Tegan Blue plums. Postharvest Biology and Technology, 43(3), 298-306. http://dx.doi.org/10.1016/j.postharvbio.2006. 10.005

Kim, H. O., Hewett, E. W., \& Lallu, N. (2001). Softening and ethylene production of kiwifruit reduced with 1-MCP. Acta Horticulturae, 553, 167-170. http://dx.doi.org/10.17660/ActaHortic.2001.553.34

Kluge, R. A., \& Jacomino, A. P. (2002). Shelf life of peaches treated with 1-methylcyclopropene. Scientia Agricola, 59(1), 69-72. http://dx.doi. org/10.1590/S0103-90162002000100010

Laohaprasit, N., Kukreja, R. K., \& Arunrat, A. (2012). Extraction of volatile compounds from 'Nam Dok Mai' and 'Maha Chanok' mangoes. International Food Research Journal, 19(4), 1445-1448.

Lazan, H., Ali, Z., Lee, K., Voon, J., \& Chaplin, G. (1986). The potential role of polygalacturonase in pectin degradation and softening of mango fruit. ASEAN Food Journal, 2, 93-98.

Liu, R., Lai, T., Xu, Y., \& Tian, S. (2013). Changes in physiology and quality of Laiyang pear in long time storage. Scientia Horticulturae, 150, 31-36. http://dx.doi.org/10.10 16/j.scientia.2012.10.017

Menniti, A. M., Gregori, R., \& Donati, I. (2004). 1-Methylcyclopropene retards postharvest softening of plums. Postharvest Biology and Technology, 31(3), 269-275. http://dx.doi.org/10.1016/j.post harvbio.2003.09.009

Nilsson, T. (2005). Effects of ethylene and 1-MCP on ripening and senescence of European seedless cucumbers. Postharvest Biology and Technology, 36(2), 113-125. http://dx.doi.org/ 10.1016/j.postharvbio.2004.11.008

Pantastico, E. R., Chattopadhyay, T. K., \& Subramanyam, H. (1975). Storage and commercial storage operations. In E. B. Pantastico (Ed.), Postharvest Physiology, Handling and Utilization of Tropical and Subtropical Fruit and Vegetables (pp. 314-338). Westport, US: AVI.

Pietro, R., Cocci, E., Romani, S., Sacchetti, G., \& Rosa, M. D. (2009). Effect of 1-MCP treatment and $\mathrm{N}_{2} \mathrm{O}$ MAP on physiological and quality changes of fresh-cut pineapple. Postharvest Biology and Technology, 51(3), 371-377. http://dx.doi.org/10.1016/j. postharv bio.2008.07.010

Pongprasert, N., \& Srilaong, V. (2014). A novel technique using 1-MCP microbubbles for delaying postharvest ripening of banana fruit. Postharvest Biology and Technology, 95, 42-45. http://dx.doi.org/10.1016/j.postharvbio.2014.04.003

Porat, R., Feng, X., Huberman, M., Galili, D., Goren, R., Goldschmidt, E. E., \& Feng, X. Q. (2001). Gibberellic acid slows postharvest degreening of 'Oroblanco' citrus fruit. HortScience, 36(5), 937-940. http://hortsci.ashspublications.org/content/36/5/937.abstract

Prusky, D., \& Keen, N. T. (1993). Involvement of preformed antifungal compounds and the resistance of subtropical fruits to fungal decay. Plant Disease, 77(2), 114-119. Retrieved from http://ww w.apsnet.org/publications/PlantDisease/BackIssues/Documents/1993Articles/PlantDisease77n02_114.PDF

Rupinder, S., \& Dwivedi, U. N. (2008). Effect of Ethrel and 1-methylcyclopropene (1-MCP) on antioxidants in mango (Mangifera indica var. Dashehari) during fruit ripening. Food Chemistry, 111(4), 951-956. http://dx.doi. org/10.1016/j.foodchem.2008.05.011

Serek, M., Sisler, E. C., \& Reid, M. S. (1995). Effects of 1-MCP on the vase life and ethylene response of cut flowers. Plant Growth Regul, 16(1), 93-97. http://dx.doi.org/10.1007/ BF00040512

Shifeng, C., Yan, Z., \& Zheng, Y. (2012). Effect of 1-methylcyclopene on senescence and quality maintenance of 
green bell pepper fruit during storage at $20{ }^{\circ} \mathrm{C}$. Postharvest Biology and Technology, 70, 1-6. http://dx.doi.org/10.1016/j.postharvbio.2012.03.005

Singh, S. P., \& Pal, R. K. (2008). Response of climacteric-type guava (Psidium guajava L.) to postharvest treatment with 1-MCP. Postharvest Biology and Technology, 47(3), 307-314. http://dx.doi.org/10.1016/j.postharvbio. 2007.08.010

Sisler, E. C., \& Serek, M. (1997). Inhibitors of ethylene responses in plants at the receptor level. Physiologia Plantarum, 100(3), 577-582. http://dx.doi.org/10.1111/j.1399-3054.1997.tb03063.x

Sozzi, G., \& Beaudry, R. M. (2007). Current perspectives on the use of 1-methylcyclopropene in tree fruit crops: an international survey. Stewart Postharvest Review, 3(2), 1-16. http://dx.doi.org/10.2212/spr.2007.2.8

SPSS. (1999). Base 9.0 for Windows Users Guide. USA.: SPSS Inc.

Thai Mango-Ma-Muang. (2008). Retrieved from http://www.simply-thai.com/Thai-Market_Fruit_Mango.html

Vásquez-Caicedo, A. L., Neidhart, S., Pathomrungsiyounggul, P., Wiriyacharee, P., Chattrakul, A, Sruamsiri, P., ... Carle, R. (2002). Physical, chemical and sensory properties of nine Thai mango cultivars and evaluation of their technological and nutritional potential. Paper presented at the International Symposium Sustaining Food Security and Managing Natural Resources in Southeast Asia-Challenges for the 21st Century. Chiang Mai, Thailand.

Vera, H., Saguy, S. I., \& Pesis, E. (2005). Postharvest application of 1-MCP to improve the quality of various avocado cultivars. Postharvest Biology and Technology, 37(3), 252-264. http://dx.doi.org/10.1016/j.postharvbio.2005. 05.003

Vidhu, A. S., Chourasia, A., \& Nath, P. (2005). Softening in mango (Mangifera indica cv. Dashehari) is correlated with the expression of an early ethylene responsive, ripening related expansin gene, MiExpA1. Postharvest Biology and Technology, 38(3), 223-230. http://dx.doi.org/10.1016/j.postharvbio. 2005.07.008

Watkins, C. B. (2006). The use of 1-methylcyclopropene (1-MCP) on fruit and vegetables. Biotechnology Advances, 24(4), 389-409. http://dx.doi.org/10. 1016/j.biotechadv.2006. 01.005

Watkins, C. B. (2008). Overview of 1-methylcyclopropene trials and uses for edible horticultural crops. HortScience, 43, 86-94.

Whitham, F. H., Blaydes, D. F., \& Devlin, R. M. (1986). Exercises in Plant Physiology (2nd ed.). New York, US: Van Nostrand Co.

Win, T. O., Srilaong, V., Heyes, J., Kyu, K. L., \& Kanlayanarat, S. (2006). Effects of different concentrations of 1-MCP on the yellowing of West Indian lime (Citrus aurantifolia, Swingle) fruit. Postharvest Biology and Technology, 42(1), 23-30. http://dx.doi.org/10.1016/j.postharvbio. 2006.05.005

Wongkaew, L., \& Likittrakoolrung, S. (2009). Pestilential diseases in 'Maha Chanok' mango. Kasikorn, 82(6), 43-47.

Wongkhot, A., Rattanapanone, N., \& Chanasut, U. (2012). BrimA, total acidity and total soluble solids correlate to total carotenoid content as indicators of the ripening process of six Thai mango fruit cultivars. Chiang Mai University Journal of Natural Sciences, 11(1), 97-103. Retrieved from http://cmuir.cmu.ac.th/handle/6653943832/38667

Xiaolin, Z., Ye, L., Jiang, T., Guox, J., \& Li, J. (2012). Limiting the deterioration of mango fruit during storage at room temperature by oxalate treatment. Food Chemistry, 130(2), 279-285. http://dx.doi.org/10.1016/j.foodchem. 2011.07.035

Yuan, G., Sun, B., Yuan, J. J., \& Wang, Q. (2010). Effect of 1-methylcyclopropen on shelf life, visual quality, antioxidant enzymes and health-promoting compounds in broccoli florets. Food Chemistry, 118(3), 774-781. http://dx.doi.org/10.1016/j.foodchem. 2009.05.062

Zhanquan, Z., Tian, S., Zhu, Z., Xu, Y., \& Qin, G. (2012). Effects of 1-methylcyclopropene(1-MCP) on ripening and resistance of jujube (Zizyphus jujuba cv. Huping) fruit against postharvest disease. LWT - Food Science and Technology, 45(1), 13-19. http://dx.doi.org/10. 1016/j.lwt.2011.07.030

Zisheng, L. (2007). Effect of 1-methylcyclopropene on ripening of postharvest persimmon (Diospyros kaki L.) fruit. LWT - Food Science and Technology, 40(2), 285-291. http://dx.doi. org/10.1016/j.lwt.2005.10.010 


\section{Copyrights}

Copyright for this article is retained by the author(s), with first publication rights granted to the journal.

This is an open-access article distributed under the terms and conditions of the Creative Commons Attribution license (http://creativecommons.org/licenses/by/3.0/). 